
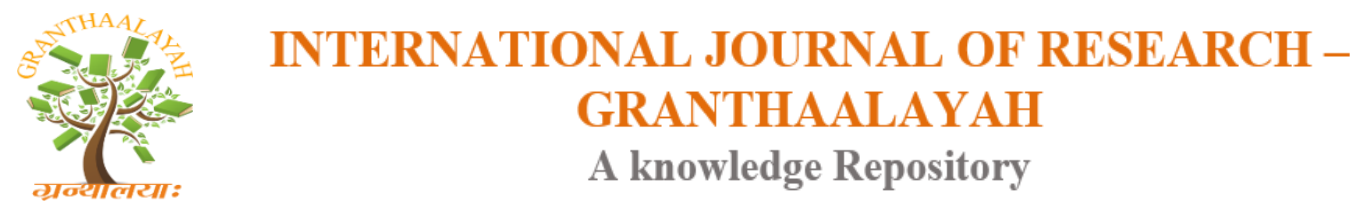

Science

\title{
USE OF ELECTRONIC INFORMATION RESOURCES BY THE FACULTY OF ENGINEERING COLLEGES - A STUDY
}

\author{
R.Ramesh $^{* 1}$, Dr. B. R. Doraswamy Naick ${ }^{* 2}$ \\ ${ }^{1}$ Research Scholar, LIS, Jawaharlal Nehru Technological University, Kakinada, Andhra Pradesh, \\ India \\ ${ }^{2}$ Assistant Professor, LIS, Jawaharlal Nehru Technological University, Kakinada, Andhra \\ Pradesh, India
}

\begin{abstract}
To study the engineering college faculties by use of electronic information resources, which are circumstances in the Kanchikacherla village engineering colleges. There are up to three engineering colleges in this village, the study mainly conducted only this engineering colleges only. This paper fundamental study is workforce use of various electronic information resources in three engineering colleges' faculty. To locate the quantity of faculty knows how to use the electronic information resources in the segment of three engineering colleges. For the purpose of study structured questionnaires were designed. A total 420 questionnaires were distributed among the faculty of three engineering colleges. There is 255 filled -up questionnaires were received back consisting of $60.71 \%$ responses only. Balance 65 questionnaires are not filled any faculty. The survey implies the how the faculty are using the electronic information resources in their teaching, research and personal subject development purpose.
\end{abstract}

Keywords: Engineering Colleges; Electronic Resources; Information; Departments; Faculty; Study.

Cite This Article: R.Ramesh, and Dr. B. R. Doraswamy Naick. (2017). "USE OF ELECTRONIC INFORMATION RESOURCES BY THE FACULTY OF ENGINEERING COLLEGES - A STUDY." International Journal of Research - Granthaalayah, 5(9), 68-79. https://doi.org/10.29121/granthaalayah.v5.i9.2017.2200.

\section{Introduction}

However, with the rapid progress in technology and the advancement in learning systems, it is now embraced by the masses. The introduction of computer was the basic of this revolution and with the passage of time, as we get hooked to smart phones, tablets, etc. These devices now have an importance place in the classrooms for learning. Books are gradually getting replaced by electronic educational materials like optical disc or pen drives. Knowledge can also be shared via the internet, which is accessible 24/7, anywhere, anytime. (The Economic Times newspaper The 
aftermath from these progressions is that libraries must reposition their parts physically, as well as remotely and electronically through the web and appropriated systems.

Using an information system seems to require three different cognitive processes. Informationseeking, knowledge acquisition and problem solving. "'Information seeking is a goal-driven activity in which needs are satisfied through problem-solving" (Brown, 1991). According to Okerson (2000), "'several factors make both possible and desirable the cooperative activity in the world of electronic information purchasing and provision'. These are: Quality of new materials and electronic forms of old materials available and Library user's expectations on the availability and access to that material. In this study there are total three engineering colleges are mainly participated in the village of Kanchikacherla. A total 420 questionnaires were distributed among the faculty and 255 filled - up questionnaires were received back consisting of $60.71 \%$ responses. Balance 65 questionnaires are not filled any faculty.

\section{Scope Of The Study}

- The study limited to the faculty working in engineering colleges of Kanchikacherla village only.

- The study is covers only engineering college's faculty of the respective institutions and not cover the students of colleges.

\section{Profile of Three Engineering Colleges}

Devineni Venkata Ramana \& Dr. Hima Sekhar MIC College of Technology (DVR \& Dr.HS MIC). Founded in 2002 under the Devineni Venkata Ramana Pranitha Memorial Trust approval by AICTE, New Delhi affiliated to JNTUK, Kakinada. The institute offers Bachelor of Technology with specialization in Civil, EEE, ECE, Mechanical, CSE (Diploma, B.Tech \& M.Tech), and MBA\& MCA. The library automated with Soul software and Web OPAC also implemented. The college is also a member of DELNET [Developing Library Network] through which the students and faculty can access the information from college membership of DELNET and the college is also subscribed the online and printed journals of different subjects.

Amrita Sai Institute of Science and Technology (ASIST) and it is organised by the trust. The college stated in the year of 2007. The college offers the B.Tech and M.Tech, MCA, MBA and Diploma Courses also. The library automated and Web OPAC also implemented. The college is also a member of DELNET [Developing Library Network] through which the students and faculty can access the information from college membership of DELNET and the college is also subscribed the online and printed journals of different subjects.

Muthavarapu Venkateswara Rao College of Engineering and Technology (MVR), it is situated in the village of paritala, this three engineering colleges are in the near of highway 65 . Founded in 2008 under the Swarna Group, the college is approval by AICTE; New Delhi affiliated to JNTUK, Kakinada. The institute offers Bachelor of Technology with specialization in Civil, EEE, ECE, Mechanical, CSE and MBA (B.Tech \& P.G). The library automated and Web OPAC also implemented. The college is also a member of DELNET [Developing Library Network] 
through which the students and faculty can access the information from college membership of DELNET and the college is also subscribed the online and printed journals of different subjects.

\section{Review of Literature}

Singh (2009) examines the search pattern of online journals among the faculty members, research scholars and post-graduate students to collect the required data. The study reveals that the majority of users are aware about the availability of online Journals. It was found that many users faced problem when using online journals and that they were interested in undergoing training on the use of online Journals.

Korobili and et al. (2011) reports on the methodology and results of a survey studying the information-seeking behaviour of philosophy and engineering graduate students at Aristotle University of Thessaloniki in Greece. The article provides statistical analysis regarding students' self-evaluations of information-seeking abilities and habits, as well as various results from the study's findings, including level of experience with computers, usage of electronic databases, and the ability to retrieve data from search engines. The survey revealed that the difference in engineering and philosophy disciplines did not significantly affect information seeking behavior.

Dr. A. Vijayakumar and Jaison Thomas (2014) made a study which highlights the preferences and importance of online resources among teachers and research scholars. The Internet and the Web are constantly influencing the development of new modes of scholarly communication; their potential for delivering goods is quite vast, as they overcome successfully the geographical limitations associated with the print media. Further, the distribution time between product publication and its delivery has been drastically reduced. The Internet can be used for efficient retrieval and for meeting the information needs.

O.Shivaraja (2015) made a study which the students and faculty members who participated in this survey are aware of electronic information sources. Even through majority of academic community use electronic information sources, most of the students and faculty members prefer print sources as well as electronic information sources. The survey shows the traditional resources will continue to be necessary components of the academic community. So, it is necessary that the academic library professionals should be proactive in working academic community to develop training program aimed at enabling them to use electronic information sources more effectively.

\section{Objectives of the Study}

1) To comprehend the data necessities understudies and use of electronic resources of the Faculty.

2) To study the preference and utilization of data available in the engineering colleges.

3) To study the satisfaction level of the faculty on the accessible electronic resources in the library.

4) To distinguish the issues confronted by the faculty for utilization of electronic resources in the engineering college libraries 


\section{Methodology}

The review technique was considered for this review since it can faculty conditions. What they think about the electronic resources and it was very much coordinated to the exploration questions taken for this review. There are up to three engineering colleges in the Kanchikacherla. The scope of the study is limited only to faculty of engineering colleges. In the study questionnaire method was used to collect the necessary data. A total 420 questionnaires were distributed among the faculty and 255 filled -up questionnaires were received back consisting of $60.71 \%$ responses. Balance 65 questionnaires are not filled any faculty.

\section{Analysis and Interpretation of Data}

Analysis shows that all the engineering colleges considered for the study have a good collection of printed information resources such as text books, reference books and Subject journals, project reports, standards, CD/DVD ROMS, newspapers and magazines. The online journals collection is found these three engineering colleges. The reason being all these libraries are members of DELNET Packages. For using the electronic resources by the faculty are in the teaching, research, general information and career advancement.

Table 1: Classification of Respondents Designation

\begin{tabular}{|c|c|c|c|c|c|}
\hline S.No & $\begin{array}{c}\text { Name of the } \\
\text { College }\end{array}$ & Professors & $\begin{array}{c}\text { Associate } \\
\text { Professors }\end{array}$ & $\begin{array}{c}\text { Assistant } \\
\text { Professors }\end{array}$ & Total \\
\hline 01. & DVR \& Dr.HS MIC & $35(13.72 \%)$ & $20(7.84 \%)$ & $42(16.47 \%)$ & $97(38.05 \%)$ \\
\hline 02. & ASIST & $31(12.15 \%)$ & $42(16.47 \%)$ & $16(6.27 \%)$ & $89(34.90 \%)$ \\
\hline 03. & MVR & $20(7.84 \%)$ & $32(12.54 \%)$ & $17(6.66 \%)$ & $69(27.05 \%)$ \\
\hline \multicolumn{2}{|c|}{ Total } & $\mathbf{8 6}(\mathbf{3 3 . 7 2 \%})$ & $\mathbf{9 4 ( 3 6 . 8 6 \% )}$ & $\mathbf{7 5}(\mathbf{2 9 . 4 2 \% )}$ & $\mathbf{2 5 5}(\mathbf{1 0 0 \%})$ \\
\hline
\end{tabular}

(Indicates the level of Respondents)

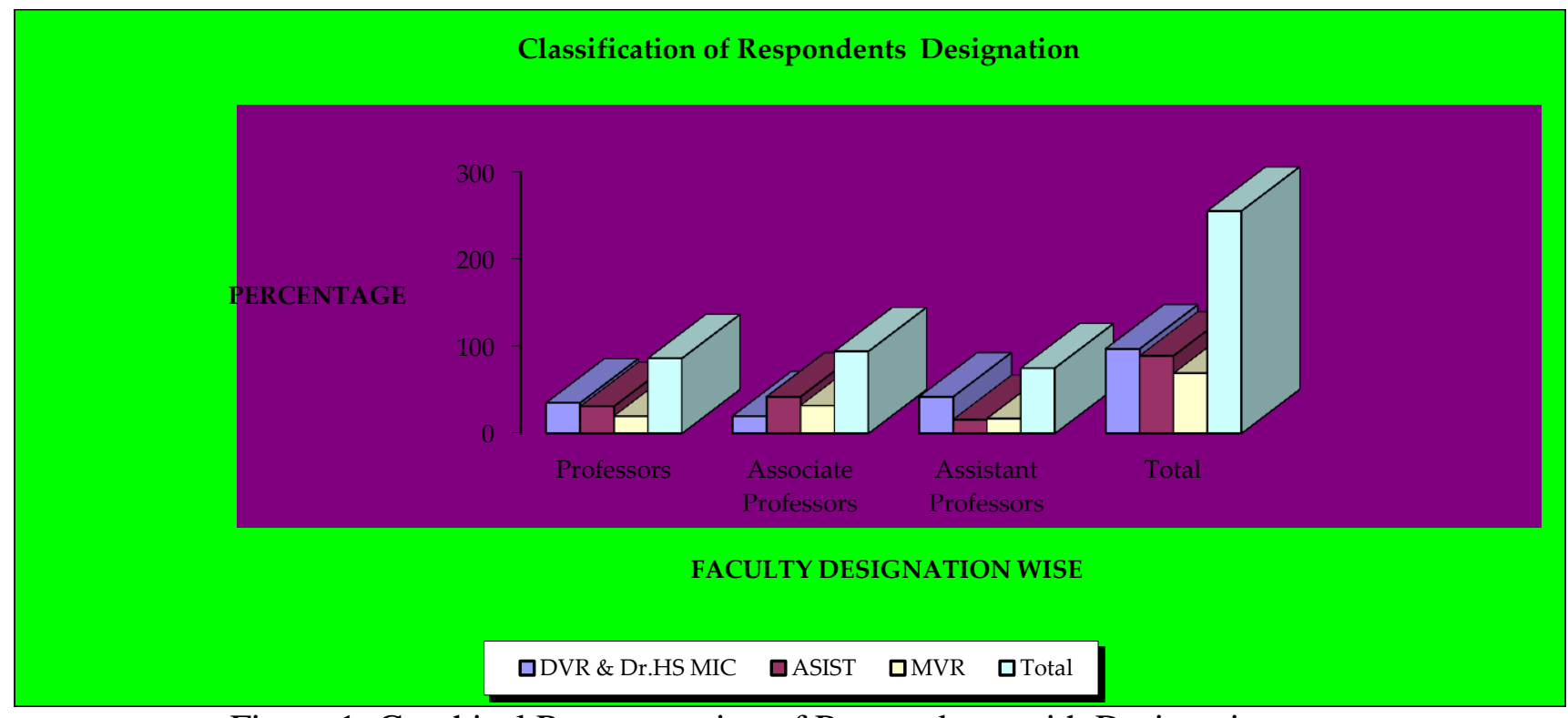

Figure 1: Graphical Representation of Respondents with Designation 
Table 1: Demonstrates the three levels of personnel positions have been seen in the review. For example, Professors, Associate Professors and Assistant Professors. 86(33.72\%) of the Professors among the respondents, 94(36.86\%) of the Associate Professor among the respondents and 75(29.42\%) of the Assistant Professors among the respondents in the review. In the total highest participated in designation wise is DVR \& Dr.HS MIC is in the percentage of 97(38.05\%), after ASIST College is in the 89(34.90\%) percentage and lastly 69(27.05\%) percentage of MVR College.

Table 2: Gender Wise Distribution

\begin{tabular}{|c|c|c|c|c|}
\hline S.No & Name of the College & Male & Female & Total \\
\hline 01. & DVR \& Dr.HS MIC & $45(17.64 \%)$ & $20(7.84 \%)$ & $65(25.49 \%)$ \\
\hline 02. & ASIST & $51(20 \%)$ & $47(18.43 \%)$ & $98(38.43 \%)$ \\
\hline 03. & MVR & $40(15.68 \%)$ & $52(20.38 \%)$ & $92(36.08 \%)$ \\
\hline \multicolumn{2}{|r|}{ Total } & $136(53.34 \%)$ & $119(46.66 \%)$ & $255(100 \%)$ \\
\hline
\end{tabular}

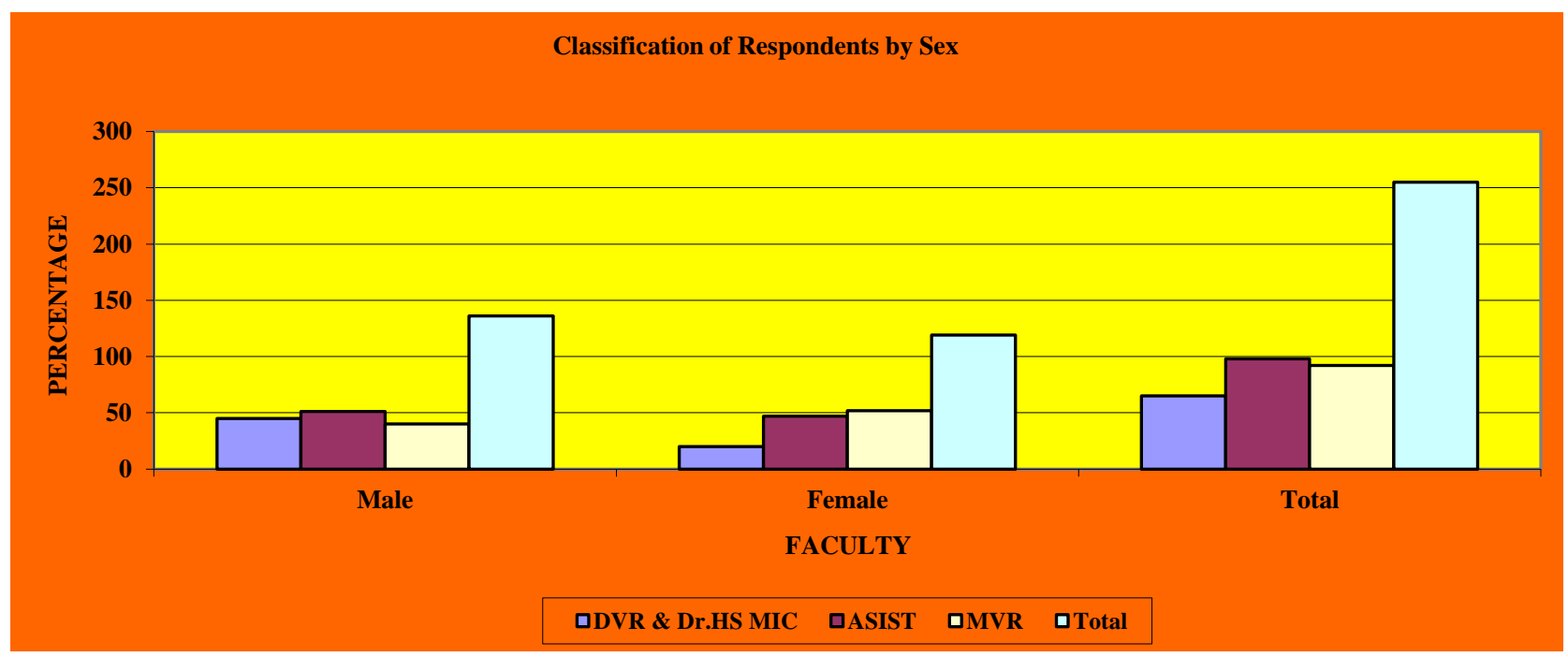

Figure 2: Graphical Representation of Respondents by Sex wise

Table 2: shows the three college's wise number of male faculty percentage and female faculty percentage. In this study ASIST college faculty (male) are participated in the percentage of $51(20 \%) \&$ Female faculty are in the $47(38.43 \%)$, after DVR \& Dr.HS MIC college faculty (male) in the percentage of $45(17.64 \%)$ \& Female faculty is in $20(7.84 \%$ ) and lastly MVR college (male) is in percentage of $40(15.68 \%)$ \& Female is in 52(20.38\%). So, the highest percentage to participate the study is $98(38.43 \%)$ of the ASIST College, after MVR college percentage is $92(36.08 \%)$ and lastly DVR \& Dr.HS MIC College is in the percentage is $65(25.49 \%)$. 
Table 3: Uses of Electronic Resources by the Faculty

\begin{tabular}{|c|c|c|c|c|c|}
\hline S.No & Purpose & $\begin{array}{c}\text { DVR \& Dr.HS } \\
\text { MIC }\end{array}$ & ASIST & MVR & Total \\
\hline 01. & Teaching & $45(17.64 \%)$ & $45(17.64 \%)$ & $32(12.54 \%)$ & $122(47.84 \%)$ \\
\hline 02. & Research & $25(9.80 \%)$ & $20(7.84 \%)$ & $12(4.70 \%)$ & $57(22.35 \%)$ \\
\hline 03. & General Information & $15(5.88 \%)$ & $10(3.92 \%)$ & $15(5.88 \%)$ & $40(15.69 \%)$ \\
\hline 04. & $\begin{array}{l}\text { Career } \\
\text { Advancement }\end{array}$ & $13(5.09 \%)$ & $11(3.92 \%)$ & $12(4.70 \%)$ & $36(14.12 \%)$ \\
\hline \multicolumn{2}{|r|}{ Total } & 98(38.43\%) & 86(33.72\%) & $71(27.84 \%)$ & $255(100 \%)$ \\
\hline
\end{tabular}

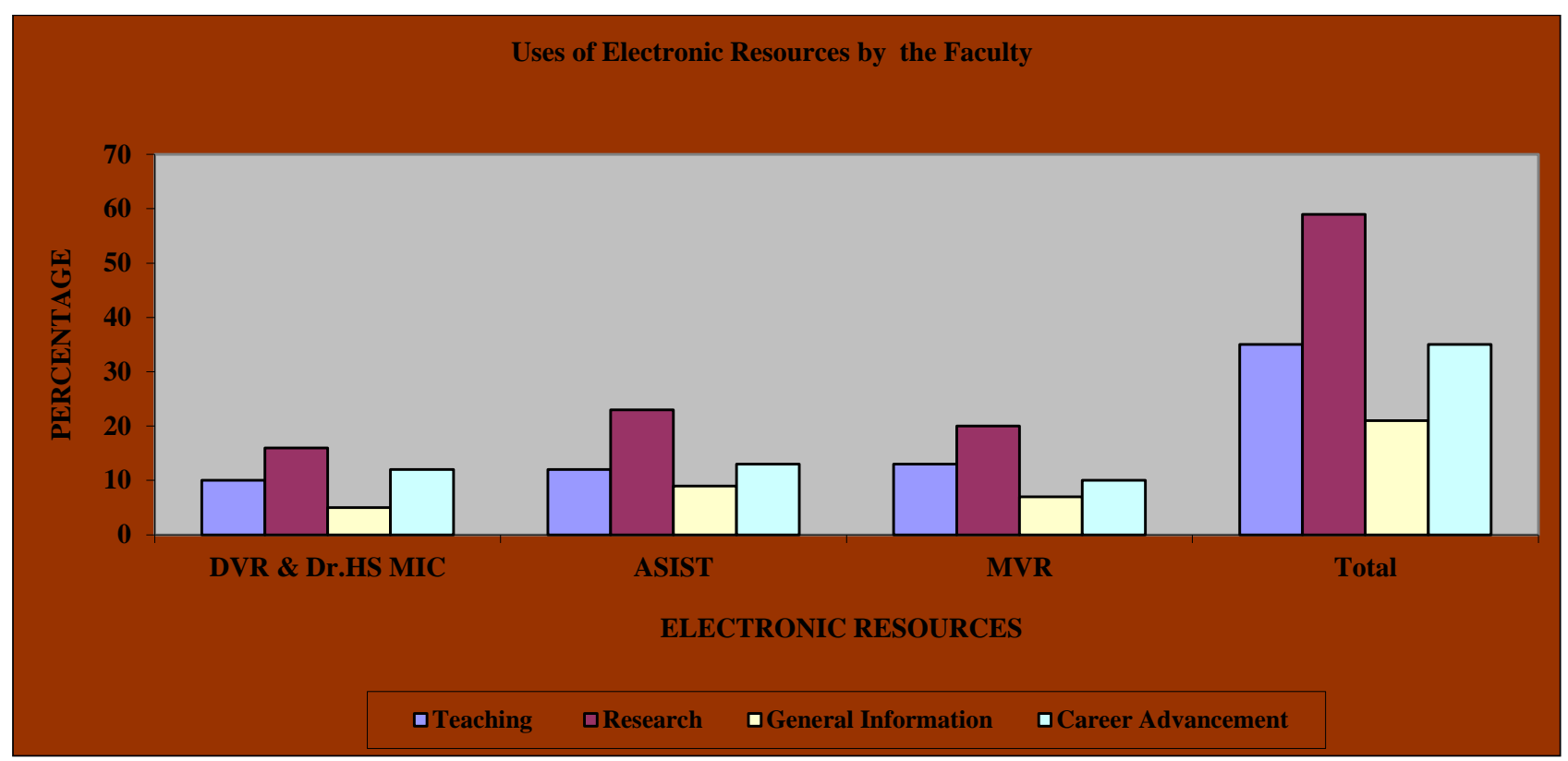

Figure 3: Graphical Representation of Use of Electronic Resources by Faculty

Table 3: shows the different college's wise faculty using the information through electronic resources. In the teaching purpose DVR \& Dr.HS MIC \& ASIST colleges are same percentage is in $45(17.64 \%) \& 45(17.64 \%)$ and MVR college is in 32(12.54\%). In the research purpose highest using the electronic resource college is DVR \& Dr.HS MIC College is in 25(9.80\%). After ASIST college is in 20(7.84\%) and the lastly MVR college is in the percentage of $12(4.70 \%)$. In the general information purpose $15(5.88 \%)$ of the percentage is bellowing to DVR \& Dr.HS MIC \& MVR college and 10(3.92\%) percentage is bellowing to ASIST college. In the columns' of career advancement wise highest percentage is bellowing to $13(5.09 \%)$ for DVR \& Dr.HS MIC after 12(4.70\%) is in MVR college and lastly ASIST college is in the percentage of 11(3.92\%). 
Table 4: Data Available in the Engineering Colleges

\begin{tabular}{|c|l|c|c|c|c|}
\hline S.No & $\begin{array}{c}\text { Data available in the } \\
\text { college }\end{array}$ & $\begin{array}{c}\text { DVR \& } \\
\text { Dr.HS MIC }\end{array}$ & ASIST & MVR & Total \\
\hline 01. & CD/DVD & $25(9.80 \%)$ & $12(4.70 \%)$ & $15(5.88 \%)$ & $52(20.39 \%)$ \\
\hline 02. & Online Databases & $22(8.62 \%)$ & $12(4.70 \%)$ & $15(5.88 \%)$ & $49(19.22 \%)$ \\
\hline 03. & Online Journals & $18(7.05 \%)$ & $26(10.19 \%)$ & $11(4.31 \%)$ & $55(21.56 \%)$ \\
\hline 04. & e-books & $15(5.88 \%)$ & $18(7.05 \%)$ & $21(8.23 \%)$ & $54(21.18 \%)$ \\
\hline 05. & e-projects & $16(6.27 \%)$ & $15(5.88 \%)$ & $14(5.49 \%)$ & $45(17.65 \%)$ \\
\hline \multicolumn{2}{|c|}{ Total } & $\mathbf{9 6 ( 3 7 . 6 6 \% )}$ & $\mathbf{8 3 ( 3 2 . 5 4 \% )}$ & $\mathbf{7 6 ( 2 9 . 8 0 \% )}$ & $\mathbf{2 5 5 ( 1 0 0 )}$ \\
\hline
\end{tabular}

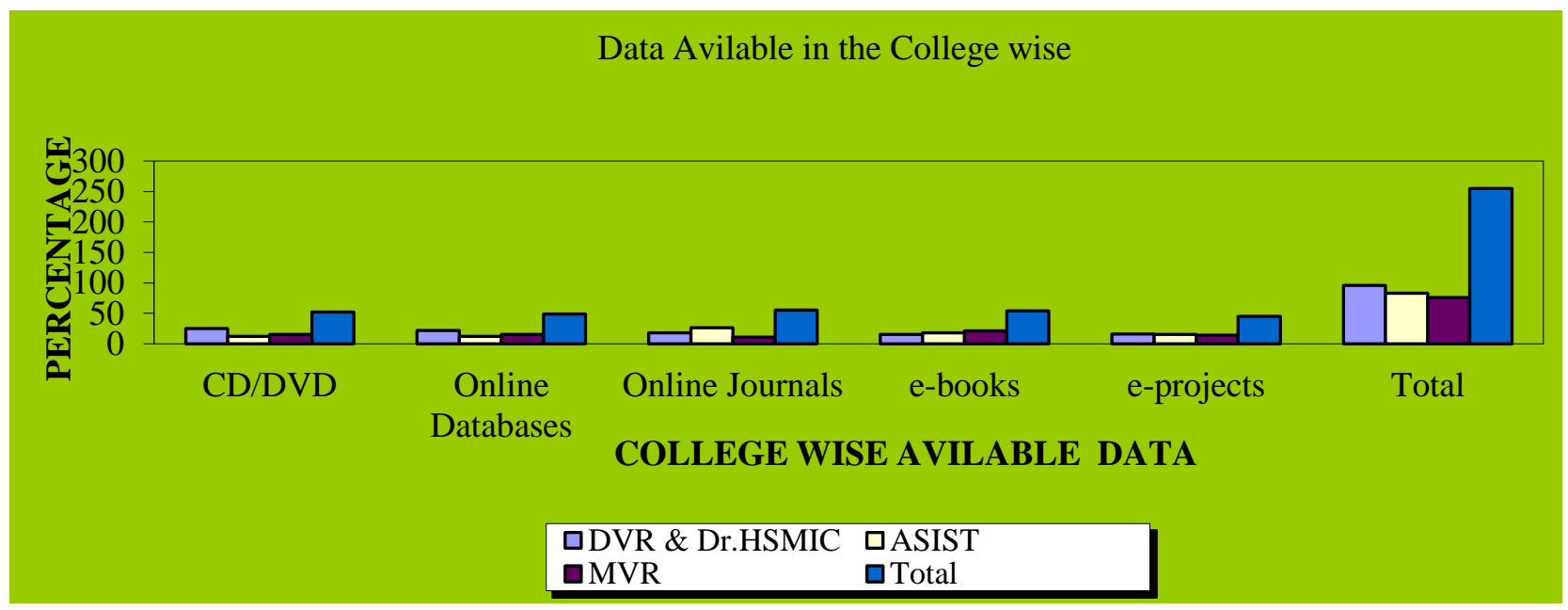

Figure 4: Graphical Representation of Data Available in the college wise

Table 4: shows the different college's wise data available in the engineering colleges. And also shows the percentage of available data in engineering colleges. In the table shows the highest percentage of available data is Online Journals, it is 55(21.56\%). In the second level e-books of $54(21.18 \%)$, after $52(20.39 \%)$, is CD/DVD and Online Databases is $49(19.22 \%)$, lastly low level of data available is e-projects is $45(17.64 \%)$. In the college wise DVR \& Dr.HS MIC is the extra data sources in the total three colleges and the percentage is $96(37.64 \%)$ after $83(32.54 \%)$ is the ASIST college and lastly MVR college is maintains data sources is $76(29.80 \%)$. So, the DVR \& Dr.HS MIC college faculty is using the highest data in the three colleges.

Table 5: Satisfaction Level of the Faculty on the Accessible Electronic Resources

\begin{tabular}{|c|c|c|c|c|c|}
\hline S.No & $\begin{array}{c}\text { Electronic } \\
\text { Resources }\end{array}$ & $\begin{array}{c}\text { DVR \& Dr.HS } \\
\text { MIC }\end{array}$ & ASIST & MVR & Total \\
\hline 01. & CD/DVD & $15(5.88 \%)$ & $12(4.70 \%)$ & $10(3.92 \%)$ & $37(14.60 \%)$ \\
\hline 02. & Online Databases & $11(4.31 \%)$ & $09(3.52 \%)$ & $16(6.27 \%)$ & $36(14.11 \%)$ \\
\hline
\end{tabular}




\begin{tabular}{|l|c|c|c|c|c|}
\hline 03. & Online Journals & $22(8.62 \%)$ & $26(10.19 \%)$ & $12(4.70 \%)$ & $60(23.52 \%)$ \\
\hline 04. & e-books & $23(9.01 \%)$ & $35(13.72 \%)$ & $30(11.76 \%)$ & $88(34.50 \%)$ \\
\hline 05. & e-projects & $11(4.31 \%)$ & $10(3.92 \%)$ & $13(5.09 \%)$ & $34(13.33 \%)$ \\
\hline \multicolumn{2}{|c|}{ Total } & $\mathbf{8 2}(\mathbf{3 2 . 1 5 \%})$ & $\mathbf{9 2}(\mathbf{3 6 . 0 7 \%})$ & $\mathbf{8 1 ( 3 1 . 7 6 \% )}$ & $\mathbf{2 5 5}(\mathbf{1 0 0 \%})$ \\
\hline
\end{tabular}

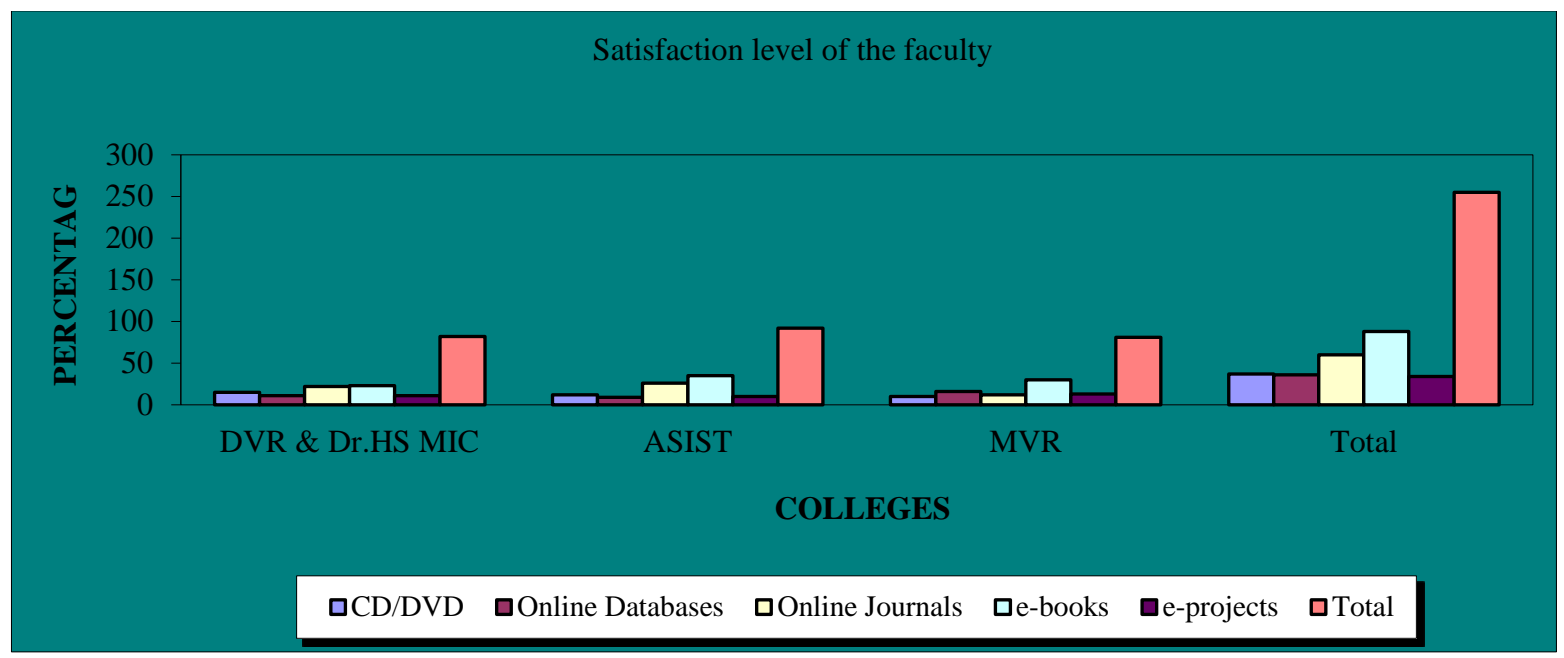

Figure 5: Graphical Representation of Satisfaction level of the faculty

Table 5: shows the different college's electronic resources satisfaction, which the data available in the engineering colleges. And also shows the percentage of satisfaction level of three engineering college faculty for using the electronic resources in the colleges. In the table shows the highest level of utilization of electronic resources in three engineering college is e-books, it is $88(34.50 \%)$, next is Online Journals for utilization percentage is 60 (23.52\%), after CD/DVD is $37(14.60 \%)$, Online Databases is $36(14.11 \%$ ) and lastly e-projects is in the percentage of $34(13.33 \%)$. So, the college wise using the electronic resources in $92(36.07 \%)$ of ASIST college, next is DVR \& Dr.HS MIC college is in $82(32.15 \%)$ and lastly MVR college percentage is different of $81(31.76 \%)$. So, overall satisfaction level for using the electronic resources college is ASIST College in the percentage of 92(36.07\%). In the second level DVR \& Dr.HIS MIC college is in $82(32.15 \%)$ and third level is MVR college in the percentage of $81(31.76 \%)$

Table 6: Issues Confronted by the Faculty for Utilization of Electronic Resources

\begin{tabular}{|c|c|c|c|c|c|c|}
\hline S.No & $\begin{array}{c}\text { Name of the } \\
\text { College }\end{array}$ & $\begin{array}{c}\text { Network } \\
\text { Issues }\end{array}$ & $\begin{array}{c}\text { Unfamiliarity } \\
\text { to Use }\end{array}$ & Prolonged & Costly & Total \\
\hline 01 . & $\begin{array}{c}\text { DVR \& Dr.HS } \\
\text { MIC }\end{array}$ & $25(9.80 \%)$ & $22(8.62 \%)$ & $13(5.09 \%)$ & $11(4.31 \%)$ & $71(27.84 \%)$ \\
\hline 02. & ASIST & $25(9.80 \%)$ & $29(11.37 \%)$ & $22(8.62 \%)$ & $23(9.01 \%)$ & $99(38.82 \%)$ \\
\hline 03. & MVR & $25(9.80 \%)$ & $23(9.01 \%)$ & $18(7.05 \%)$ & $19(7.45 \%)$ & $85(33.34 \%)$ \\
\hline \multicolumn{2}{|r|}{ Total } & $75(29.41 \%)$ & $74(29.01 \%)$ & $53(20.78 \%)$ & $53(20.78 \%)$ & $255(100 \%)$ \\
\hline
\end{tabular}


Issues conftonted by the faculty for using ER

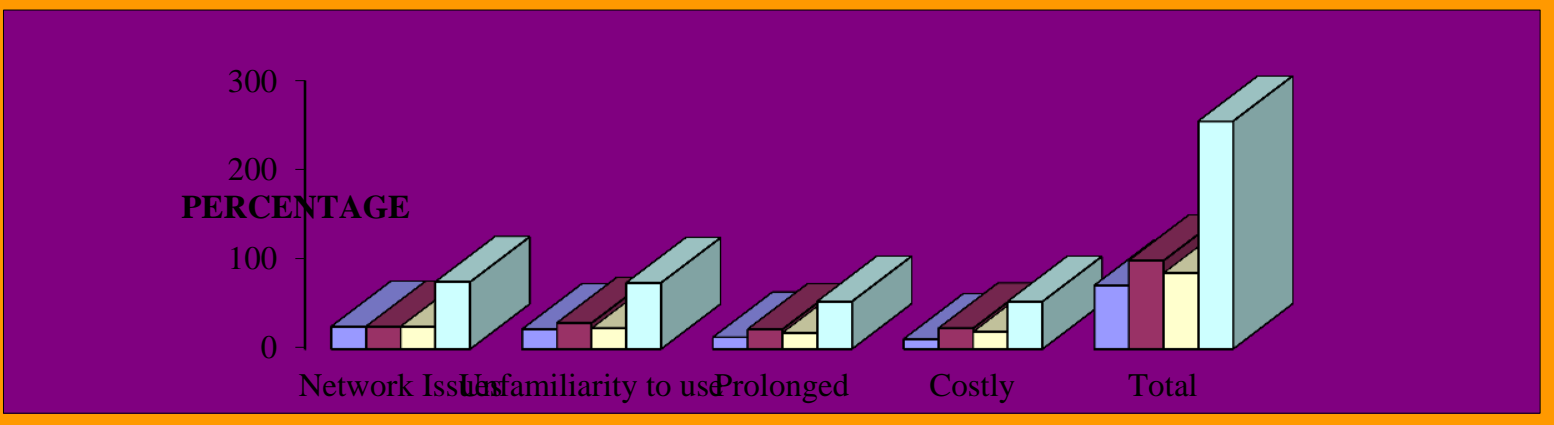

ISSUES CONFTONTED BY THE FACULTY

口DVR \& Dr.HS MIC 口ASIST 口MVR 口Total

Figure 6: Graphical Representation of Issues Confronted

Table 6: shows the different college's wise issues confronted by the faculty for utilization of electronic resources in three engineering colleges. In the table and Figure shows the college wise problems faced while using electronic resources. The comparison of network issues is in 75 (29.41\%) of the three engineering colleges are same. 74 (29.01\%) of Unfamiliarity to use of in the table and graphics shows. Prolonged and Costly columns are same percentage in the table and graphic. ASIST is the highest percentage shows in the table of 29(11.37\%), after 23(9.01\%) of MVR college and lastly DVR \& Dr.HS MIC college percentage is 22(8.62\%). So the table and graphic show the overall issues confronted in ASIST College is the highest percentage for raising the question. After MVR college in the percentage of $85(33.34 \%)$ and the finally $71(27.84 \%)$ of the DVR \& Dr.HS MIC college. So, the faculty has to acquire knowledge to using the electronic resources within the college and take some special class to be arranged.

\section{Findings of the Study}

1) Designation wise classification of respondent's in 97 (38.05\%) is DVR \& Dr.HIS MIC college, after $89(34.90 \%)$ is the ASIST college and lastly $69(27.05 \%)$ is belong to MVR college. 94(36.86\%) of Associate Professors are the highest designation to participated in three colleges. After 86(33.72\%) is Professors in three colleges and Assistant Professors in the percentage of $75(29.42 \%)$.

2) In the review shows the college wise male faculty and female faculty for ASIST college is in the percentage of 98(38.43\%), 92(36.08\%) is the MVR college and 65(25.49\%) of DVR \& Dr.HS MIC college. In the gender wise male faculty percentage is $136(53.34 \%)$ and female faculty is in the percentage of 119(46.66\%).

3) In the college wise $98(38.43 \%)$ is belong to DVR \& Dr.HS MIC college for teaching, research, general information and career advancement purpose. After 86(33.72\%) is belong to ASIST college and lastly $71(27.84 \%)$ is the MVR college. In the table shows the highest percentage for their internal and external development purpose is DVR \& Dr. HS MIC College. 
4) In the table \& graphic 7.4 shows the data available in the electronic resources (CD/DVD, Online Databases, Online Journals, e-books and e-projects). The highest data available college is DVR \& Dr.HS MIC college 96(37.66\%) after 83(32.54\%) is the ASIST college and lastly MVR college is in the percentage of $76(29.80 \%)$.

5) In the table \& graphic 7.5 shows satisfaction level of faculty for using the electronic resources in the engineering colleges. 92(36.07\%) is highest satisfaction for this study belong to ASIST college faculty. After DVR \& Dr.HS MIC college faculty satisfaction level percentage is $82(32.15 \%)$ and lastly MVR college faculty is in the percentage of $81(31.76 \%)$.

6) In the table and graphic number 7.6 shows the issues confronted in the engineering college wise faculty for using the electronic resources. In the percentage of $75(29.41 \%)$ is belongs to network issues of the three colleges. In the point of unfamiliarity to use is for the three college percentage is $74(29.01 \%)$, percentage of $53(20.78 \%$ ) is the prolonged issue for three colleges. In the costly wise percentage is $53(20.78 \%)$ for three colleges.

\section{Conclusion}

The results of this study point to some issues on which particular observation is required. There is need to measure internet, online journals, online databases, CD/DVD. Demonstrates the three levels of personnel positions have been seen in the review. In the total highest participated in designation wise is DVR \& Dr.HS MIC is in the percentage of 97(38.05\%), after ASIST College is in the $89(34.90 \%)$ percentage and lastly 69(27.05\%) percentage of MVR College. Table -II Shows the three colleges' wise number of male faculty percentage and female faculty percentage. So, the highest percentage to participate the study is 98(38.43\%) of the ASIST College, after MVR college percentage is $92(36.08 \%)$ and lastly DVR \& Dr.HS MIC College is in the percentage is $65(25.49 \%)$. Table -III shows the three college's faculty using the information through electronic resources. In the general information purpose $15(5.88 \%)$ of the percentage is bellowing to DVR \& Dr.HS MIC \& MVR college and 10(3.92\%) percentage is bellowing to ASIST college. In the columns' of career advancement wise highest percentage is bellowing to $13(5.09 \%)$ for DVR \& Dr.HS MIC after 12(4.70\%) is in MVR college and lastly ASIST college is in the percentage of 11(3.92\%). Table-IV shows the three college's electronic resources satisfaction. So, overall satisfaction level faculty for using the electronic resources of the college is ASIST College in the percentage of 92(36.07\%). In the second level DVR \& Dr.HIS MIC college is in $82(32.15 \%)$ and third level is MVR college in the percentage of $81(31.76 \%)$. So the table and graphic show the overall issues confronted in ASIST College is the highest percentage for raising the question. After MVR college in the percentage of 85(33.34\%) and the finally $71(27.84 \%)$ of the DVR \& Dr.HS MIC college. So, the faculty has to acquire knowledge to using the electronic resources within the college and take some special class to be arranged. So, the above results are indicates the faculty must needs a training analysis of various segments of the academic population should be undertaken. Earlier to that, faculty use of the internet and other needs to be studied. There is also a need to look at the training programs offered by the engineering college libraries to see how effective they are. There is also a need to investigate the level of information evaluation skills of electronic resources users and create an 
awareness of the importance of this activity in selecting and using electronic resources for teaching, learning, general information, research and career advancement.

\section{References}

[1] Dr. B. R. Doraswamy Naick (2016), Networking of Engineering College Libraries Affiliated to JNTU, Kakinada in Andhra Pradesh: A Prototype Design based on Information Seeking Behaviour of Faculty. International Journal of Digital Library Services, Vol-06, January-March 2016, Issue-1, and ISSN: 2250-1142 (Online), ISSN 2349-302X (Print).

[2] Library Technology Reports, Expert guides to library systems and services, A publication of American Library Association, Electronic Resources Management Systems: A Workflow Approach by ElsaAnderson, ALA Tech source, April-2014, vol-50/no.3 and ISSN 0024-2586.

[3] Faculty Attitudes toward Electronic Resources, E-Content by Bruce Heterick, director JSTOR in July/August-2000, provide by Educes, http://www.educause.edu/

[4] Adika, G. (2003), "Internet use among faculty members of universities in Ghana", Library Review, Vol. 52 No. 1, pp. 29-37.

[5] Sunil Kumar Satpathy \& Biswanath Rout (2010) Use of E-Resources by the Faculty Members with Special Reference to CVRCE, Bhubaneswar, DESIDOC Journal of Library \& Information Technology, Vol. 30, No. 4, July 2010, pp. 11-16.

[6] Ganski, Kate L. (2008). An Evaluation of the Accessibility of E-resources from Theological Library Websites. Theological Librarianship: An Online Journal of the American Theological Library Association, 1 (1). 38-45.

[7] Kaur, Baljinder and Verma, Rama. (2009). Use of Electronic Information Resources: A Case Study of Thapar University. The Electronic Library, 27 (4). 611-622.

[8] Dr. B. R. Doraswamy Naick and Neelima Bachalla "Application of digital forensics in digital libraries”, International Journal of Library \& Information Science (IJLIS), Volume 5, Issue 2, May-Aug 2016, pp. 89-94, Article -ID: IJLIS_05_02_010

[9] Woods, K, Lee, C.A., \& Garfinkel, S. (2011). Extending digital repository architectures to support disk image preservation and access. In Proceedings of the 11th Annual International ACM/IEEE Joint Conference on Digital Libraries (pp.57-66). New York, NY: Association for Computing Machinery. Retrieved from: http://dx.doi.org/10.1145/1998076.1998088.

[10] Prof. Shilpa Shantaram Pawar, Applications of Cloud Computing in Digital Libraries with Reference to Improve the Functionality. International Journal of Library \& Information Science, 5(2), 2016, pp.1-6

[11] R.Ramesh, Research scholar, JNTU-Kakinada \& B.R.Doraswamy Naick, Use of Electronic Resources by faculty members of engineering colleges in Jaggayyyapet - A study, International Journal of Research in Library Science, ISSN: 2455-104X, Volume 2, Issue 2 (JulyDecember) 2016, 30-37.

[12] Dr. B. R. Doraswamy Naick, and Dr.K.Kumar assistant professor, 'exploit of information resource in Jawaharlal Nehru technological university Kakinada affiliated engineering colleges library users: a survey', International Journal of Digital Library Services, Vol-04, Jan.March 2014, Issue-1, www.IJDLS.in, (ISSN: 2250-1142), P (93-117).

\section{About Author}

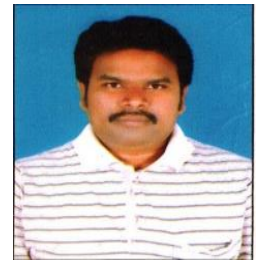

Ramesh Rayapudi is working as Assistant Librarian in K L University Guntur Andhra Pradesh, I received the MLISC degree from Andhra University, Vishakhapatnam, Andhra Pradesh India and he is qualified the APSLET-2016 in Library and information Science and now I am pursuing Ph.D. in Library and 
Information Science under Esteemed guidance of Dr. B. R. Doraswamy Naick, Assistant Professor, LIS, Jawaharlal Nehru Technological University (JNTUK) Kakinada Andhra Pradesh, I Attended many Conferences and Presented a papers and his Papers Published In Reputed National and International Journals.

\footnotetext{
*Corresponding author.

E-mail address: ramesh.mlisc2006@ gmail.com
} 